\title{
REVIEW
}

\section{Influence of food restriction on mammalian immunity}

\author{
Josef Berger \\ Department of Preclinical and Clinical Studies, Faculty of Health and Social Studies, University of South \\ Bohemia, České Budějovice, Czech Republic
}

Received $28^{\text {th }}$ September 2012.

Revised $14^{\text {th }}$ November 2012.

Published online $7^{\text {th }}$ December 2012.

\begin{abstract}
Summary
There is often an imbalance between the intake of n- 6 and n-3 polyunsaturated fatty acids in patients with inflammatory and autoimmune diseases. Oxidative damage and the production of reactive oxygen species by various immune cells follow during the ageing process. Caloric restriction induces a transcriptional response of the genes known to inhibit oxidative stress, tumourigenesis, splicing mRNA and inflammation. On the other hand, calorie malnutrition causes the depression of many immune functions. The accessibility of nutritional factors seems to be an important cause of circannual rhythms. Lowered food intake as an adverse effect of chemotherapy may be why the immune system is altered. Nutrients influence several diseases including diabetes, obesity, inflammatory immune dysfunctions, and neuropathies as well as behavioural characteristics and life span.
\end{abstract}

Key words: oxidative damage; gene; circannual; adverse effect; diabetes; neuropathy; life span

\section{WHY FOOD IS INFLUENTIAL IN THE AGEING PROCESS}

The earliest evidence that food restrictions slow the ageing process and extend median and maximum lifespan in rodents was presented in the 1930s by McCay and co-workers (McCay et al. 1935). Food deprivation enhances learning and motivation (Forestell et al. 2001). It seems to be a consequence of the upregulation of peripheral stress responsive genes in the mammalian brain mediated by corticosterone (Guarnieri et al. 2012). Food restriction also affects behavioural priorities including decreases in sexual motivation (Klingerman et al. 2011).

Josef Berger, Department of Preclinical and Clinical Studies, Faculty of Health and Social Studies, University of South Bohemia, Emy Destinnové 46, 37005 České Budějovice, Czech Republic

ㅁㅛㅛ berger@jcu.cz

용 +420389037617

(C) Journal of Applied Biomedicine
The physiological effects of restricted food intake can be connected with the uptake of fatty acids. The ability of certain fatty acids to influence the immune system has been recognized for nearly 40 years, and most of the research has focused on two major families of polyunsaturated fatty acids, the n-6 (popularly referred to as omega-6 fatty acids) and the n-3 (omega-3). Much important information on the mechanisms of the effects of fatty acids has been generated in experiments on laboratory animals and in vitro assays (Fritsche 2007).

The imbalance between n-6 and n-3 polyunsaturated fatty acids intake has been frequently observed in patients with inflammatory and autoimmune diseases (Lands 2005). Mammals cannot synthesize fatty acids with a double bond past the $\Delta 9$ position (Innis 2000). Dietary n-3 fatty acids alone increase insulin sensitivity; combining n-3 fatty acids and caloric restriction should have a synergistic effect during ageing: it decreases inflammatory mediators, insulin and glucose and increases adiponectin in food restricted ageing mice (Fernandes 2008, for review).

The precise mechanism of the influence of food on lifespan is not yet known. Several theories have been 
proposed, and among them, two (Masoro 2006) are supported by recent experimental data: (i) oxidative damage, and (ii) attenuation of insulin-like signalling.

Oxidative damage and ROS production by various immune cells follow during ageing in many target tissues and are now linked to functional loss in metabolic energetics (Nunn et al. 2009). Long-term food-restriction decreases the rate of mitochondrial $\mathrm{H}_{2} \mathrm{O}_{2}$ production and mtDNA oxidative damage in various tissues (Vendelbo and Nair 2011).

Weindruch and co-workers (Kayo et al. 2001, Weindruch et al. 2001) have also made several key observations concerning the influence of ageing and caloric restriction on the transcriptional profile. Nutrients can affect gene expression at the cellular level: (i) as ligands for transcription factor receptors; (ii) by causing changes in the concentrations of substrates or intermediates involved in gene regulation or cell signalling and (iii) by altering signal transduction pathways and signalling (Kaput and Rodriguez 2004, Raqib and Cravioto 2009).

The upregulation of antioxidant enzymes by n-3 fatty acids and food deprivation is linked to the regulation of genes encoding ROS scavenging proteins (Sreekumar et al. 2002). Caloric restriction induces a transcriptional response of genes known to inhibit oxidative stress, tumorigenesis, splicing mRNA and inflammation but it does not induce a genome-wide reversal of age-associated gene expression patterns (Swindell 2009).

\section{NUTRITIONAL IMMUNOLOGY}

The earliest evidence implicating the role of nutrition in the immune function came from J. F. Mendel in 1810 who described thymic atrophy in malnourished people in England. The discovery of vitamins in the early 1900s was followed by reports on their contribution to immunity and other host defences (Beisel 1992). It is clear that protein-calorie malnutrition causes the depression of many immune functions (see Suskind 1977).

Basic research in animals has identified many general immune mechanisms through which the immune system is influenced by nutrition: some nutrients, e.g., vitamins E, A, and D, directly regulate signalling pathways, while some dietary factors have a regulatory influence on hormones that, in turn, modulate the immune system (see Raqib and Cravioto 2009). The constituents of food interact with genes and their products to alter phenotype; gene-nutrient interactions are studied by nutrigenomics (Kaput et al. 2005).
The constituents of food represent important environmental factors. Accessibility of nutritiens can, therefore, depend on other parts of the temporally dynamic environment, for example, seasons. Circannual rhythms have been described (cf. Berger 2008) in many characteristics of human subjects and various animal species. When experimental animals are isolated in a laboratory vivarium with an artificial constant light regime and pathogen barrier, their seasonal changes are in the same way as for non isolated, conventional animals (Berger 1981a, 1983); it is changes in the stocked diet which seem to be the synchronizer of some circannual rhythms. Physiological trade-offs between the reproductive and immune system mediate part of the seasonal changes (Martin et al. 2008b).

The susceptibility of elderly people to infectious diseases is well known. The cellular immune system is altered but innate immunity is enhanced. The important events of immune ageing are modifications of lymphocyte subsets with an accumulation of memory cells, a decrease in the proliferative response, and a chronic inflammatory state. (Cretel et al. 2010). Age-associated changes to immunity may also contribute to the age-associated increasing incidence of most cancers, because many cancers are immunogenic (Pavelec et al. 2010). Presumably, premature immunosenescence may lead to inadequate immune reactions which are observed, for example in the familiar form of Alzheimer's disease (RichartzSalzburger et al. 2010).

Nutrition is an important factor in livestock breeding and not only as a source of structural body components. Infectious diseases reduce productivity and diminish animal welfare; appropriate nutrition may help in minimizing the incidence of diseases by enhancing immunity (see Klasing 2007).

\section{CALORIC RESTRICTION EFFECTS IN MAMMALIAN BIOMODELS}

Earlier studies undertaken in caloric restriction in mice in order to ascertain changes in immune functions were carried out by Fernades et al and Walford et al (Fernandes 2008, for review). They reported marked changes in IL-2 production, Th1/Th2 subsets, changes in insulin receptors and an increased longchain FA, increased levels of free-radical scavenging antioxidant enzymes and down regulate expression of several genes linked to inflammation by using oligonucleotide microarrays.

Food restriction increases antibody response in Siberian hamsters but not bacterial killing ability 
(Zysling et al. 2009). It induces a lower number of antigen-induced memory T cells with age, maintaining higher levels of IL-2 with age (Fernandes et al. 1997).

Food restriction has no significant effect on the phytohaemaglutinin response, immunoglobulin $G$ and $\mathrm{M}$ concentrations and white blood cell counts, while it decreases corticosterone levels in Mongolian gerbils ( $\mathrm{Xu}$ et al. 2011). The proliferative response to phytohemaglutinin and concavalin $\mathrm{A}$ is higher, while cytosolic superoxide dismutase activity is lower in the spleen cells of food-restricted rats (Byun et al. 1995). A drop in B-cells but no changes in the mitogen response of these cells has been documented, and an increase in natural cell activity and $\mathrm{O}_{2}^{-}$production by macrophages in mice. (Nakamura et al. 1990). Food restriction can increase mitogen induced $\mathrm{T}$ cell proliferation and retard its age related decrement (Utsuyama et al. 1996).

Thymic involution was observed in rats fed with both a restricted quantity and a protein-free diet (Konno et al. 1993). Two weeks of food restriction reduces total splenocytes, total splenic B lymphocytes and splenic B lymphocytes producing $\mathrm{IgG}$, but does not affect IgG1 and IgG2 in deer mice (Martin et al. 2008a). Mouse spleen cells from food restricted mice produce higher levels of IL-2 and lesser prostaglandin E2 (Venkatraman and Fernandes 1992). An increase of Thy $-1^{+}$spleen cells with a proportional decrease in $\mathrm{Ig}^{+}$cells, and increased percentages of $\mathrm{CD}^{+}$and $\mathrm{CD}^{+}$cells with food restriction were shown in mice (Boissonneault and Harrison 1994).

In contrast, food restriction had little influence on both $\mathrm{CD}^{+}$and $\mathrm{CD} 8^{+} \mathrm{T}$ cells and $\mathrm{B}$ cells in rats except for a reduction of granulocyte numbers (Stefanski 2001). In other studies, energy restricted diets increased the concentration of $\mathrm{CD}^{+}, \mathrm{CD} 8^{+}, \mathrm{CD} 45 \mathrm{RA}$ and immunoglobulin A-, M-, G- cells in spleen and colon, respectively (Nayak et al. 2009).

Food restriction can enhance drug intake (Carroll et al. 1979). A lowered food intake as an adverse effect of chemotherapy may be the reason why the immune system is altered (Berger 1981b, Berger et al. 2005).

\section{EFFECTS OF NUTRIENTS ON IMMUNITY}

There are a number of food allergies - adverse immune responses to a food (Pinheiro and Prates 2011). Gluten intolerance, known as celiac disease, with autoimmune pathologies, is accompanied by neurodegenerative changes (Hernandez-Lahoz et al. 2011). On the other hand, dietary restriction may be beneficial not only in ageing, but also in diabetes and obesity while improper diets can negatively impact both physical and psychological activity and potentially some aspects of immunity (Jolly 2007).

n-3 fatty acids have been known to be essential to normal growth and health since the 1930s (MolendiCoste et al. 2011, Ramakrishnan 2011). They decrease cytokines IL-1, IL-6, IL-8, TNF $\alpha$, GM-CSF, NFкB, prostaglandin E2 TLR4, cyclooxygenase-2, PGE, LTB $_{4}$, VCAM-1 and VEGFR2 (Fernandes 2008, Ibrahim et al. 2011).

Combinatorial therapy using an antioxidant diet and immunotherapy can be a powerful strategy for improving brain function in neuropathies through the enhancement of multiple molecular pathways (Corman and Head 2008). S-adenosyl methionine dietary supplementation reduces the number of extracellular amyloid- $\beta$ deposits, phosphorylated tau protein and caspase cleaved tau, and may therefore modulate the time course of Alzheimer's disease (Lee et al. 2012).

Inflammation, which coexists with immune dysfunction, may decrease life span (Finch and Crimmins 2004). An increased dietary intake of vegetable-derived bioactive compounds may retard age-related immune dysfunctions and prolong life span (Galassetti and Pontello 2006, Delgado et al. 2012).

Food and its composition represent very important environmental influences on both animal and human health. These factors can change the progression of diseases as well as longevity through gene regulations.

\section{REFERENCES}

Beisel WR. History of nutritional immunology: introduction and overview. J Nutr. 122: 591-596, 1992.

Berger J. Seasonal influences on circadian variations in blood picture of laboratory rats. Zwierzeta Lab. 18: 3-25, 1981a.

Berger J. Changes in marrow myelopoietic and lyphoid cell counts after repeated cyclophosphamide administration in the rat. Haematologia. 14: 407416, $1981 b$.

Berger J. Seasonal influences on circadian rhythms in the blood picture of SPF rats housed under artificial illumination. Folia Haematol. 110: 5570. 1983.

Berger J. Advances in chronohaematology. J Appl Biomed. 6: 65-72, 2008.

Berger J, Machackova M, Berger Z. Effects of feed restriction on the nucleolar structure and function in lymphocytes. Basic Clin Pharmacol Toxicol. 97: 36-237, 2005. 
Boissonneault GA, Harrison DE. Obesity minimizes the immunopotentiation of food restriction in $\mathrm{Ob} /$ Ob mice. J Nutr. 124: 1639-1646, 1994.

Byun DS, Venkatraman JT, Yu BP, Fernanes G. Modulation of antioxidant activities and immuneresponse by food restriction in aging Fischer-344 rats. Aging Clin Exper Res. 7: 40-48, 1995.

Carroll ME, France CP, Meisch RA. Food deprivation increases oral and intravenous drug intake in rats. Science. 205: 319-321, 1979.

Corman CW, Head E. The canine (dog) model of human aging and disease: dietary, environmental and immunotherapy approaches. J Alzheimer Dis. 15: 685-707, 2008.

Cretel E, Veen I, Pierres A, Bongrand P, Gavazzi G. Immunosenescence and infections, myth or reality? Med Malad Infect. 40: 7-18, 2010.

Delgado J, del Pilar Terrón M, Garrido M, Barriga C, Spino J, Paredes SD, Rodríguez AB: Jerte Valley cherry-based product modulates serum inflammatory markers in rats and ringdoves. $\mathrm{J}$ Appl Biomed. 10: 41-50, 2012.

Fernandes G. Progress in nutritional immunology. Immunol Res. 40: 244-261, 2008.

Fernandes G, Venkatraman JT, Turturro A, Attwood VG, Hart RW. Effect of food restriction on life span and immune functions in long-lived Fischer-344 x Brown Norway F-1 rats. J Clin Immunol. 17: 85-95, 1997.

Finch CE, Crimmins EM. Inflammatory exposure and historical changes in human life-spans. Science. 305: 1736-1739, 2004.

Forestell CA, Schellinck HM, Boudreau SE, LoLordo VM: Effect of food restriction on acquisition and expression of a conditioned odor discrimination in mice. Physiol Behav. 72: 559-566, 2001.

Fritsche K. Important Differences Exist in the doseresponse relationship between diet and immune cell fatty acids in humans and rodents. Lipids. 42: 961-979, 2007.

Galassetti P, Pontello A. Dietary effects on oxi-dation of low-density lipoprotein and atherogenesis. Curr Atheroscler Rep. 8: 523-529, 2006.

Guarnieri DJ, Brayton CE, Richards SM, MaldonadoAviles J, Trinko JR, Nelson J, Tailor JR, Gourley SL, DiLeone RJ. Gene profiling reveals a role for stress hormones in the molecular and behavioral response to food restriction. Biol Psychiatr. 71: 358-365, 2012.

Hernandez-Lahoz C, Mauri-Capdevila G, Vega-Villar J, Rodrigo L. Neurogluten: patología neurológica por intoleranci al gluten. Rev Neurol. 53: $287-$ 300, 2011.

Ibrahim A, Mbodji K, Hassan A, Aziz M, Boukhettala N, Coëffier M, Savoye G, Déchelotte P, Marion-
Letellier R.Anti-inflammatory and anti-angiogenic effect of long Chin n-3 polyunsaturated fatty acids in intestinal microvascular endothelium. Clin Nutr. 30: 678-687, 2011.

Innis SM. Essential fatty acids in infant nutrition: lessons and limitations from animal studies in relation to studies on infant fatty acid requirements. Am J Clin Nutr. 71: 238S-244S, 2000.

Jolly CA. Is dietary restriction beneficial for human health, such as for immune function? Curr Opin Lipidol. 18: 53-57, 2007.

Kaput J, Rodriguez RL. Nutritional genomics: the next frontier in the postgenomic era. Physiol Genomics. 16: 166-177, 2004.

Kaput J, Ordovas JM, Ferguson L, van Ommen B, Rodriguez RL, Allen L, Ames BN, Dawson K, German B, Krauss R, Malyj W, Archem MC et al. The case for strategic international alliances to harness nutritional genomics for public and personal health. Br J Nutr. 94: 623-632, 2005.

Kayo T, Allison DB, Weindruch R, Prolla TA. Influences of aging and caloric restriction. Proc Nat Acad Sci USA. 98: 5093-5098, 2001.

Klasing KC. Nutrition and the immune system. Br Poultry Sci. 48: 525-537, 2007.

Klingerman CM, Patel A, Hedges VL, Meisel RL, Schneider JE. Food restriction dissociates sexual motivation, sexual performance, and the rewarding consequences of copulation in female Syrian hamsters. Behav Brain Res. 223: 356-370, 2011.

Konno A, Utsuyama M, Kurashima C, Kasai M, Kimura S, Hirokawa K. Effects of a protein-free diet or food restriction on the immune-system of Wistar and buffalo rats at different ages. Mech Ageing Develop. 72: 183-197, 1993.

Lands WE. Dietary fat and health: the evidence and the politics of prevention: careful use of dietary fats can improve life and prevent disease. Ann N Y Acad Sci. 1055: 179-192, 2005.

Lee S, Lemure CA, Frost JL, Shea TB. Dietary supplementation with S-adenosyl methionine delayed amyloid- $\beta$ and tau pathology in 3xTg-AD mice. J Alzheimer Dis. 28: 423-431, 2012.

Martin LB, Navara KJ, Bailey MT, Hutch CR, Powell ND, Sheridan JF, Nelson RJ. Food restriction compromises immune memory in deer mice (Peromyscus maniculatus) by reducing spleenderive antibody-producing B cell numbers. Physiol Biochem Zool. 81: 366-372, 2008a.

Martin LB, Weil ZM, Nelson RJ. Seasonal changes in vertebrate immune activity: mediation by physiological trade-offs. Phil Trans Royal Soc B-Biol Sci. 363: 321-339, 2008b. 
Masoro EJ. Caloric restriction and aging: controversial issues. J Gerontol A Biol Sci Med Sci. 61: 14-19, 2006.

McCay CM, Cromwell MF, Maynard LA. The effect of retarded growth upon the length of lifespan and ultimate body size. J Nutr. 10: 63-79, 1935.

Molendi-Coste O, Legry V, Leclercq IA. Why and how meet n-3 PUFA dietary recommendations? Gastroenterol Res Pract. 2011, art no UNSP 364040, 2011.

Nakamura K, Aoke A, Hosokawa T, Rokutan K, Koyarna K, Nishi Yoshida YA, Kawai K. Effect of food-restriction stress on immune response in mice. J Neuroimmunol. 30: 23-29, 1990.

Nayak BN, Friel JK, Rempel CB, Jones PJH. Energy-restricted diets result in higher numbers of $\mathrm{CD}^{+}, \mathrm{CD}^{+}$, immunoglobulins (A, M, and $\mathrm{G})$, and CD45RA cells in spleen and $\mathrm{CD}^{+}$, immunoglobulin A, and CD45RA cells in colonic lamina propria of rats. Nutr Red. 29: 487-493, 2009.

Nunn AVW, Bell JD, Guy GW. Lifestyle-induced metabolit inflexibility and accelerated ageing syndrome: insulin resistence, firne or foe? Nutr Metab. 6: art no 16, 2009.

Pawelec G, Derhovanessian E, Larbi A. Immunosenescence and cancer. J Geriatr Oncol. 1: 20-26, 2010.

Pinheiro A, Prates S. Alergia alimentar múltipla. Acta Méd Port. 24: 453-456, 2011.

Raqib R, Cravioto A. Nutrition, immunology, and genetics: future perspectives. Nutr Rev. 67(Suppl. 2): S227-S236, 2009.

Ramakrishnan U. Fatty acid status and maternal mental health. Matern Child Nutr. 7: 99-111, 2011.

Richartz-Salzburger E, Stransky E, Laske C, Koulet N. Vorzeitige Immunalterung: ein pathogenetischer Faktor bei Alzheimer-Demenz? Nervenartzt. 81: 837-843, 2010

Sreekumar R, Unnikrishnan J, Fu A, Nygren J, Short KR, Schimke J, Barazzoni R, Nair KS. Effects of caloric restriction on mitochondrial function and gene transcripts in rat muscle. Am J Physiol Endocrinol Metab. 283: E38-43, 2001.

Stefanski V. Effets of psycosocial stress or food restriction on body mass and boy cellular immunity in laboratory rats. Stress Hlth. 17: 133140, 2001.

Suskind RM (ed.). Malnutrition and the immune response. New York: Raven Press, 1977.

Swindell WR. Genes and gene expression modules asociated with caloric restriction and gang in the laboratory mouse. BMC Genomics. 10: 585, art no 585, 2009.

Utsuyama M, Ichikawa M, Konno SA, Fujita Y, Hirokawa K. Retardation of the age-associated decline of immune functions in aging rats under dietary restriction and daily physical exercise. Mech Ageing Develop. 91: 219-228, 1996.

Vendelbo MH, Nair KS. Mitochondrial longevity pathway. Bioch Biophys Acta Mol Cell Res. 1813(SI): 634-644, 2011.

Venkatraman J, Fernandes G. Modulation of agerelated alterations in membrane-composition and receptor-associated immune functions by food restriction in Fischer-344 rats. Mech Ageing Develop. 63: 27-44, 1992.

Weindruch R, Kayo T, Lee CK, Prolla TA. Microarray profiling of gene expression in aging and its alteration by caloric restriction in mice. J Nutr. 131: 918S-923S, 2001.

Xu DL, Liu XY, Wang DH. Food restristion and refeeeding have no effect on cellular and humoral immunity in Mongolian gerbils (Meriones unguiculatus). Physiol Biochem Zool. 84: 87-98, 2011.

Zysling DA, Garst AD, Demas GE. Photoperiod and food restriction differentially affect reproductive and immune responses in Siberian hamsters Phodopus sungorus. Func Ecol. 23: 979-988, 2009. 